\title{
FAKTOR-FAKTOR YANG BERHUBUNGAN DENGAN PRNYAKIT JANTUNG KORONER DI POLIKLINIK JANTUNG RST. DR. REKSODIWIRYO. PADANG TAHUN 2018
}

\author{
Susi Irawati ${ }^{1}$, Rebbi Permata Sari ${ }^{2}$, Diana Arianti ${ }^{3}$ \\ ${ }^{1}$ STIKes Alifah, Padang 25000 \\ susidayus45@gmail.com \\ ${ }^{2}$ STIKes Alifah, Padang 25000 \\ rebbi.permatasari@gmail.com \\ ${ }^{3}$ STIKes Alifah, Padang 25000 \\ dianaarianti84@gmail.com
}

\begin{abstract}
ABSTRAK
Penyakit jantung koroner merupakan penyebab kematian nomor satu di dunia.Menurut statistik dunia ada 9,4juta kematian setiap tahun yang disebabkan oleh penyakit kardiovaskuler dan $45 \%$ kematian tersebut disebabkan oleh penyakit jantung koroner. Data dari ruangan Poliklinik Jantung RST. Dr. Reksodiwiryo. Padang, jumlah rata-rata kunjungan pasien yang berkunjung keinstalasi Poliklinik Jantung yaitu dari bulan Oktober sampai Desember 2018 tercatat sebanyak 583 orang. Tujuan penelitian untuk mengetahui faktor-faktor yang Berhubungan dengan PJK di Poliklinik Jantung RST. Dr. Reksodiwiryo. Padang.Jenis penelitian ini adalah survey analitik dengan desain cross sectional study. Penelitian ini telah dilakukan di ruang poliklinik jantung RST. Dr Reksodiwiryo Padang pada bulan April 2018 2018. Jumlah populasi 583 orang, jumlah sampel sebanyak 45 responden, waktu pengambilan data dari tanggal 27 Desember 2017 sampai dengan April 2018 dengan teknik Accidental Sampling. Data diolah secara komputerisasi dan dianalisis secara univariat berupa distribusi frekuensi dan analisa bivariat menggunakan ujichi-square ( $\mathrm{p}=$ value $\leq 0,005)$. Hasil penelitian menunjukkan lebih dari separuh pasien mengalami PJK $(51,1 \%)$, hipertensi $(51,1 \%)$, merokok $(57,8 \%)$, memiliki riwayat penyakit jantung di keluarga $(53,3 \%)$ Adanya hubungan yang bermakna antara hipertensi $(\mathrm{p}=0,025 \%)$ dan merokok $(\mathrm{p}=0,000)$, dan riwayat penyakit jantung di keluarga $(\mathrm{p}=$ $0,000 \%$ ) dengan PJK. Faktor-faktor yang berhubungan dengan PJK yang terbukti bepengaruh terhadap kejadian PJK dan merupakan fator risiko PJK pada kelompok hipertensi. Merokok, riwayat penyakit jantung di keluarga. Diharapkan kepada petugas dipoliklinik jantung RST. Dr. Reksodiwiryo Padang untuk memberikan motovasi kepada klien dan keluarga untuk untuk melakukan kontrol rutin dan teratur terhadap faktor-faktor yang berhubungan dengan penyakit jantung koroner
\end{abstract}

\section{Kata Kunci : PJK, Hipertensi, Merokok dan Riwayat Penyakit Jantung di Keluarga}

\begin{abstract}
Coronary heart disease is the number one cause of death in the world. According to world statistics there are 9.4 million deaths each year caused by cardiovascular disease and $45 \%$ of those deaths are caused by coronary heart disease. Data from the room Polyclinic Heart Army Hospital Dr.Reksodiwiryo Padang, the average number of visits of patients who visit the installation of Polyclinic Heart from Oktober to desember 2017 recorded as many as 583 people. The purpose of this study was to determine the relationship factors associated with coronary heart dieasein patients with coronary heart disease in heart polyclinic Army Hospital. Dr. Reksodiwiryo Padang. This types of research is survey analytic with cross sectional studied design. This research has been conducted on the space clinical cardiac Army Hospital Dr.Reksodiwiryo. Padang in April 2018. Total population of 583 people, the total sample of 45 respondents, data retrieval time from 27 December 2017 until april 2018 with Accidental Sampling technique. Data is processed in a computerized and analyzed by univariate from of frequency distribution and bivariate analysis using chi-square test $(\mathrm{p}=\mathrm{value} \leq 0,005)$. The result showed more than half of patients had coronary heart disease (51.1\%), hipertensy $(51,1 \%)$,risksmooking $(57,8 \%)$, history of heart disease in the family $(53,3 \%)$. The existence of a
\end{abstract}


significant association between hipertensy $(\mathrm{p}=0,025)$ smooking $(\mathrm{p}=0,004)$, and history of heart disease $(\mathrm{p}=0,022 \%)$. with coronary heart disease. Suggested to the departement of health workes Army HopitalDr. ReksodiwiryoPadang to conduct nursing counseling about factors associated with coronary heart disease and performed heart healthy gymnastics, in order to increase patient insight about coronary heart disease.

\section{Keywords : Chest pain, Physical Activity, and Stress.}

\section{PENDAHULUAN}

Dunia kesehatan memperbincangkan mengenai penyakit jantung, karena penyakit jantung merupakan suatu penyakit yang cukup menakutkan dan membunuh bagi kesehatan. Penyakit jantung disebabkan berbagai faktor yang mempengaruhinya, di Negara Indonesia faktor perekonomian juga bisa mempengaruhi meningkatnya penyakit jantung koroner, semakin meningkatnya perekonomian menyebabkan pola hidup masyarakat semakin berubah dan menyebabkan pula perubahan kesehatan masyarakat. Dan berbagai diagnosis penyakit jantung pun terus berkembang dan bermacammacam diagnosis jantung yang telah ditemukan pada saat ini (Erasta, 2012 ).

Berdasarkan data World Health Organization( $W H O$ ) bahwa penyakit jantung koroner menempati angka urutan pertama dari sepuluh penyakit yang mematikan, angka kematian terbanyak akibat penyakit jantung ditemukan sebanyak $35 \%$ atau sekitar 1,8 juta jiwa kasus kematian akibat penyakit jantung. Menurut statistic dunia ada 9,4 juta kematian setiap tahunnya yang disebabkan kardiovaskuler dan $45 \%$ disebabkan oleh jantung koroner (WHO, 2014).

Berdasarkan data dari Rikesdas (2013), menyatakan penyakit jantung koroner di Indonesia sebesar $0,5 \%$ dan berdasarkan diagnosis dari pervalensi penyakit jantung koroner sebesar 1,5\%. Pervalensi PJK meningkat seiring bertambahnya usia (65-74 tahun) meningkat dari 2,0\%-3,6 \%, dan menurun pada saat usia $\geq 75$ tahun. Kalau dilihat dari prevalensi PJK menurut jenis kelamin, perempuan lebih tinggi mengalami PJK dibandingkan dengan lakilaki dengan perbandingan $1,6 \%$ pada perempuan dan $1,3 \%$ pada laki-laki.

Berdasarkan data dari Dinas Kesehatan Provinsi, Sumatera Barat merupakan urutan ke-3 besardari seluruh Indonesia dengan prevalensi kejadian penyakit jantung koroner yaitu sebesar
0,6 \% atau sebanyak 20,567 orang, dan jumlah penderita PJK terbanyak terdapat di provinsi Jawa Barat yaitu sebanyak 160,812 orang.dan penderita PJK terendah di provinsi Maluku Utara sebanyak 1,436 orang. Berdasarkan gejala dari prevalensi penyakit jantung koroner di Sumatera Barat diperkirakan 4,400 jiwa meningggal setiap tahunnya akibat serangan jantung (Dinas Kesehatan Provinsi Sumatera Barat, 2016).

Menurut Lecture Notes (2012) beberapa faktor-faktor yang berhubungan dengan penyakit jantung koroner antara lain peningkatan kolesterol, merokok, obesitas, diabetes melitus, hipertensi, jenis kelamin, riwayat keluarga, kepribadiann (stres) dan aktifitas fisik, alkohol, infeksi, kelas sosial, geokrafis, faktor-faktor tersebut menyebabkan pasokan oksigen gagal memenuhi kebutuhan oksigen, karena penurunan pasokan sebagai akibat gangguan aliran arteri koroner. Gangguan tekanan darah dan kolesterol dapat menimbulkan penyakit jantung dan pembuluh darah diantaranya seperti hipertensi dan hiperkolesterolemia. Sekarang ini penyakit jantung masih menjadi penyebab utama kematian di Indonesia. Kejadian penyakit jantung koroner (PJK) pada hipertensi sering dikaitkan dan secara langsung berhubungan dengan tingginya tekanan darah sistolik. Penelitian Framingham selama 18 tahun terhadap penderita berusia 45-75 tahun mendapatkan hipertensi sistolik merupakan faktor pencetus terjadinya angina pektoris dan miokard infark (Kemenkes RI, 2014).

Berdasarkan penelitian yang dilakukan oleh Taufik dkk, 2016 mengenai "Analisa Faktor Resiko Penyakit Jantung Koroner Penderita Rawat Jalan Rumah Sakit Dokter Pringadi Medan" didapatkan kesimpulan yakni penyakit jantung koroner mempunyai pengaruh besar seperti kebiasaan merokok, riwayat penyakit keluarga, dan hipertensi sebesar 42,9\% terhadap kejadian kasus penyakit jantung koroner.

Berdasarkan survey awal yang telah peneliti lakukan pada bulan April 2018 di Poliklinik Jantung RS. Tentara Dr. Reksodowiryo Padang, dengan mewawancarai 10 pasien 
penyakit jantung koroner yang berobat jalan, 2 orang diantaranya berjenis kelamin Pria berumur $<55$ tahun menyatakan sakit jantung koroner dengan riwayat perokok berat dan pola hidup tidak sehat, 4 orang berjenis kelamin wanita, dan 2 orang berjenis kelamin pria menyatakan ada riwayat penyakit jantung di keluarga dan sakit hipertensi, DM, dan kebiasaan merokok sebanyak 2orang.

Tujuan penelitian untuk mengetahui faktorfaktor yang Berhubungan dengan PJK di Poliklinik Jantung RST. Dr. Reksodiwiryo

\section{METODA PENELITIAN}

Jenis penelitian Survei Analitik dengan pendekatan Cross Sectional Penelitian ini dilakukan di di Poliklinik Jantung RST Dr. Reksodiwiryo Padan. Populasi dalam penelitian ini adalah seluruh pasien penyakit yang berkunjung ke Poliklinik dan sampel sebanyak 45 orang, dengan Purposive Sampling dengan kriteria inklusi pasien yang mengalami penyakit jantung koroner dan dapat diajak komunikasi. Pengolahan data melalui analisa data secara univariat dan bivariat menggunakan uji chisquare

\section{HASIL}

\section{a. Karakteristik responden}

1. Umur

Tabel 1

Distribusi Frekkuensi Umur Responden di Poliklinik Jantung RST Dr. Reksodiwiryo Padang Tahun 2018

\begin{tabular}{lcc}
\multicolumn{3}{c}{ Padang Tahun 2018 } \\
\hline Umur & $\mathrm{F}$ & $\%$ \\
\hline$\geq$ 55 tahun & 29 & 64,4 \\
$<55$ tahun & 16 & 35,6 \\
\hline Jumlah & 45 & 100,0 \\
\hline \multicolumn{2}{c}{ Pada tabel diatas dapat dilihat dari }
\end{tabular}

45 responden 29 orang $(64,4 \%)$ memiliki umur $\geq 55$ tahun.

\section{Pendidikan}

Tabel 2

Distribusi Frekuensi Pendidikan Responden di Poliklinik Jantung RST Dr. Reksodiwiryo Padang Tahun 2018

\begin{tabular}{lcc}
\hline Pendidikan & F & $\%$ \\
\hline SD & 5 & 11,1 \\
SMP & 17 & 37,8 \\
SMA & 20 & 44,4
\end{tabular}

\begin{tabular}{lcc}
\hline PT & 3 & 6,7 \\
\hline Jumlah & 45 & 100,0 \\
\hline
\end{tabular}

Pada tabel di atas dapat dilihat bahwa dari 45 responden 20 orang $(44,4 \%)$ memiliki pendidikan SMA

3. Pekerjaan

Tabel 3

Distribusi Frekuensi Pekerjaan Responden di Poliklinik Jantung RST Dr. Reksodiwiryo PadangTahun 2018

\begin{tabular}{lcc}
\hline Pekerjaan & $\mathrm{F}$ & $\%$ \\
\hline PNS & 3 & 6,7 \\
Wiraswasta & 15 & 33,3 \\
Petani & 10 & 22,2 \\
Ibu & 17 & 37,8 \\
Tangga & & \\
\hline Jumlah & & 100,0 \\
\hline
\end{tabular}

Dari tabel di atas dapat dilihat bahwa dari 45 responden 17 orang $(37,8 \%)$ responden sebagai ibu rumah tangga.

\section{Jenis Kelamin}

Tabel 4

Distribusi Frekuensi Pekerjaan responden di Polillinik Jantung RST DR. Reksodiwiryo Padang Tahun 2018

\begin{tabular}{lcc}
\hline Jenis Kelamin & $\mathrm{F}$ & $\%$ \\
\hline Laki-laki & 26 & 57,8 \\
Perempuan & 19 & 42,2 \\
\hline Jumlah & 45 & 100,0 \\
\hline
\end{tabular}

Pada tabel di atas dapat dilihat bahwa dari 45 responden 26 orang $(57,8 \%)$ responden berjenis kelamin laki-laki.

\section{b. Analisa Univariat}

Analisis univariat digunakan untuk mengetahui rata-rata dari masing-masing variabel yang diteliti, bertujuan untuk menjelaskan atau mendiskripsikan karakteristik setiap variabel penelitian. Variabel independen adalah kebiasaan merokok, hipertensi, riwayat penyakit jantung dikeluarga dan variabel dependen adalah kejadian penyakit jantung koroner, sebagai mana terlihat pada tabel berikut ini :

\section{Kejadian Penyakit Jantung Koroner \\ Tabel 5}

Distribusi Frekuensi Kejadian Penyakit Jantung Koroner di Poliklinik Jantung RST. Dr. Reksodiwiryo Padang Tahun 2018

\begin{tabular}{lcc}
\hline Kejadian PJK & F & $\%$ \\
\hline Ya & 23 & 51,1 \\
Tidak & 22 & 48,9 \\
\hline
\end{tabular}




\begin{tabular}{l}
\hline Jumlah \\
Pada tabel diatas dapat dilihat \\
bahwa dari 45 responden 23 orang \\
$(51,1 \%)$ mengalami kejadian penyakit \\
jantung koroner.
\end{tabular}

\section{Kejadian Hipertensi}

Tabel 6

Distribusi Frekuensi Kejadian Hipertensi di Poliklinik Jantung RST. Dr. Reksodiwiryo Padang Tahun 2018

\section{$(53,3 \%)$ memiliki riwayat penyakit} jantung di keluarga.

c. Analisis Bivariat

\section{Hubungan Hipertensi dengan Kejadian Penyakit Jantung Koroner Tabel 9}

Hubungan Hipertensi dengan Kejadian Penyakit Jantung Koroner di Poliklinik Jantung RST Dr. Reksodiwiryo Padang Tahun 2018

\begin{tabular}{|c|c|c|c|c|c|c|c|c|}
\hline Kejadian Hipertensi & f & $\%$ & & & nyak & Jant & & $P$ \\
\hline Hipertensi (tekanan darah & 23 & 51,1 & & & Ko & ner & & Value \\
\hline atau pernah & & & Hipertens1 & & $\mathrm{a}$ & & lak & \\
\hline hipertensi & & & & $\mathrm{F}$ & $\%$ & $\mathrm{f}$ & $\%$ & \\
\hline Tekanan darah normal (tidak & 22 & 48,9 & Hipertensi & 16 & 69,6 & 7 & 30,4 & 0,025 \\
\hline $\begin{array}{ll}\text { pernah } & \text { mengalami } \\
\text { hipertensi) } & \end{array}$ & & & $\begin{array}{l}\text { Tekanan } \\
\text { larah normal }\end{array}$ & 7 & 31,8 & 15 & 68,2 & \\
\hline Jumlah & 45 & $100, \overline{0}$ & Jumlah & 23 & 51,1 & 22 & 48,9 & \\
\hline
\end{tabular}

Pada tabel di atas dapat dilihat bahwa dari 45 responden 23 orang $(51,1 \%)$ mengalami hipertensi.

\section{Resiko Merokok}

Tabel 7

Distribusi Frekuensi Kebiasaan Merokok di Poliklinik Jantung RST Dr. Reksodiwiryo Padang Tahun 2018

f $\%$

Resiko Merokok

merokok (berhenti merokok $26 \quad 57,8$

setelah 4 th)

Tidak merokok (telah berhenti $19 \quad 42,2$ merokok selama 4 th)

\begin{tabular}{lll}
\hline Jumlah & 45 & 100,0 \\
\hline
\end{tabular}

Pada tabel di atas dapat dilihat bahwa dari 45 responden 26 orang $(57,8 \%)$ responden memiliki kebiasaan perokok.

\section{Riwayat penyakit jantung di Keluarga} Tabel 8

Distribusi Frekuensi Riwayat Keluarga di Poliklinik Jantung RST Dr. Reksodiwiryo Padang Tahun 2018

\begin{tabular}{|c|c|c|c|c|c|c|c|c|}
\hline \multicolumn{3}{|c|}{ Padang ranun 2018} & \multirow{2}{*}{\multicolumn{6}{|c|}{$\begin{array}{c}\text { Padang } \\
\text { Tahun } 2018 \\
\end{array}$}} \\
\hline $\begin{array}{c}\text { Riwayat penyakit } \\
\text { jantungdi Keluarga }\end{array}$ & $\mathrm{f}$ & $\%$ & & & & & & \\
\hline $\mathrm{Ya}$ & 24 & 53,3 & \multicolumn{6}{|c|}{ Penyakit Jantung } \\
\hline Tidak & 21 & 46,7 & \multirow{3}{*}{-Resiko Merokok } & \multicolumn{4}{|c|}{ Koroner } & $P$ \\
\hline Jumlah & 45 & 100,0 & & \multicolumn{2}{|c|}{$\mathrm{Ya}$} & \multicolumn{2}{|c|}{ Tidak } & value \\
\hline $\begin{array}{ccc} & \text { Pada tabel } \mathrm{d} \\
\text { bahwa dari } 45 \text { res }\end{array}$ & & dilih & & $\mathrm{f}$ & $\%$ & $\mathrm{f}$ & $\%$ & \\
\hline
\end{tabular}

Pada tabel di atas dapat dilihat bahwa kejadian penyakit jantung koroner lebih tinggi pada responden yang mengalami hipertensi (tekanan darah tinggi) $(69,6 \%)$ dibandingkan yang bertekanan darah normal (31,8\%). Sedangkan yang tidak mengalami penyakit jantung koroner lebih tinggi pada responden yang mengalami tekanan darah normal $(68,2 \%)$ dibandingkan dengan responden yang hipertensi $(30,4 \%)$. Pada responden yang tekanan darah normal sebanyak 7 orang $(31,8 \%)$ yang mengalami penyakit jantung koroner, didapatkan karna adanya kebiasaan merokok, berjenis kelamin laki-laki dan karna ada riwayat penyakit jantung di keluarga.

Hasil uji statistik Chi-Square didapatkan nilai $\mathrm{p}$ value $0,025 \quad(\mathrm{p}<0,05)$ artinya terdapathubungan hipertensi dengan kejadian penyakit jantung koroner di Poliklinik Jantung RST. Dr. Reksodiwiryo Padang tahun 2018. Kejadian Penyakit Jantung Koroner Tabel 10

Hubungan Kebiasaan Merokok dengan

Kejadian Penyakit Jantung Koroner di Poliklinik Jantung RST Dr. Reksodiwiryo Padang Tahun 2018
2. Hubungan Kebiasaan Merokok dengan 


$\begin{aligned} & \text { Merokok } \\ & \text { (berhenti }\end{aligned}$
merokok <
tahun

\section{Hubungan Riwayat Penyakit Jantung di Keluarga dengan Kejadian Penyakit Jantung Koroner}

\section{Tabel 11 \\ Hubungan Riwayat Penyakit Jantung di \\ Keluarga dengan Kejadian Penyakit \\ Jantung Koroner di Poliklinik Jantung RST Dr. Reksodiwiryo Padang Tahun 2018}

\begin{tabular}{cccccc}
\hline Riwayat & \multicolumn{3}{c}{ Penyakit Jantung Koroner } & P \\
\cline { 2 - 5 } Penyakit & \multicolumn{2}{c}{ Ya } & \multicolumn{2}{c}{ Tidak } & Value \\
\cline { 2 - 4 } $\begin{array}{c}\text { Jantung di } \\
\text { Keluarga }\end{array}$ & $\mathrm{F}$ & $\%$ & $\mathrm{f}$ & $\%$ & \\
\hline Ya & 21 & 87,5 & 3 & 12,5 & 0,000 \\
\hline Tidak & 2 & 9,5 & 19 & 90,5 & \\
\hline Jumlah & 23 & 51,1 & 22 & 48,9 & \\
\hline
\end{tabular}

Pada tabel di atas dapat dilihat bahwa kejadian penyakit jantung koroner lebih tinggi pada responden yang memiliki riwayat penyakit jantung di keluarga $(87,5 \%)$ dibandingkan yang tidak memiliki riwayat penyakit jantung di keluarga $(9,5 \%)$. Sedangkan yang tidak mengalami penyakit jantung koroner lebih tinggi pada responden yang tidak memiliki riwayat penyakit jantung di keluarga (90,5\%) dibandingkan dengan yang memiliki riwayat penyakit jantung di keluarga (12,5\%).Pada 0,00 responden yang tidak memiliki riwayat penyakit jantung di keluarga sebanyak 2 orang $(9,5 \%)$, ditemukan ada penyakit jantung korener yaitu pada responden yang memiliki hipertensi dan kebiasaan merokok, berjenis kelamin laki-laki.

Hasil uji statistik Chi-Square didapatkan nilai $\mathrm{p}$ value $0,000 \quad(\mathrm{p}<0,05)$ artinya terdapat hubungan riwayat keluarga dengan kejadian penyakit jantung koroner di Poliklinik Jantung RST Dr. Reksodiwiryo Padang tahun 2018.

\section{PEMBAHASAN}

\section{A. Analisi Univariat}

\section{Kejadian Penyakit Jantung Koroner}

Berdasarkan hasil peneltian didapatkan bahwa dari 45 responden 23 orang $(51,1 \%)$ mengalami kejadian penyakit jantung koroner.

Hasil penelitian ini sejalan dengan penelitian sebelumnya yang dilakukan oleh Taufik dkk, 2016 mengenai "Analisa Faktor Resiko Penyakit Jantung Koroner Penderita Rawat Jalan Rumah Sakit Dokter Pringadi Medan" didapatkan kesimpulan yakni lebih dari separoh $(52,8 \%)$ responden mengalami penyakit jantung koroner.

Penyakit jantung koroner (PJK) adalah penyakit yang juga disebut penyakit jantung iskemik paling sering disebabkan karena sumbatan plak ateroma pada arteri koroner. Arteri koroner adalah arteri yang memasok nutrisi dan oksigen ke otot jantung (miokard). Penampilan klinis PJK sangat bervariasi. Nyeri dada biasanya merupakan gejala yang paling menonjol pada angina pectoris stabil, angina tidak stabil, angina prinzmetal, angina mikro vaskuler dan infark miokar akut, sungguhpun demikian tampilan klinis PJK dapat terjadi tanpa nyeri dada atau dengan nyeri dada yang tidak menonjol, misalnya iskemia miokard tersamar, gagal jantung, aritmia, dan mati mendadak (Rilantono, 2012).

Dari hasil penelitian, kasus PJK paling banyak terjadi pada kelompok usia 45-64 tahun. Hal ini menunjukkan bahwa insiden PJK meningkat setelah usia 45 tahun. Hasil ini sejalan dengan penelitian 
yang dilakukan oleh Fang, Shaw dan Keenan di Amerika Serikat tahun 2011 yang mendapatkan tingginya kejadian PJK pada kelompok usia 45-64 tahun. Hasil penelitian oleh Siregar dkk.di RS Dr. Pirngadi Medan tahun 2009 juga melaporkan sebagian besar penderita PJK berusia di atas 55 tahun (78,6\%). Hal ini sesuai dengan teori yang menyatakan bahwa sebelum usia 40 tahun, jarang timbul penyakit serius, sedangkan dariusia 40 hingga 60 tahun, insiden infark miokardmeningkat lima kali lipat.

Menurut asumsi peneliti dari karakteristik responden yang banyak ditemukan reponden yang mengalami kejadian penyakit jantung koroner bila dilihat dari segi umur ditemukan umur $\geq 55$ tahun yaitu sebanyak (13 orang)dari 23 responden yang mengalami PJK dan berjenis kelamin laki-laki(18 orang), dari segi pendidikan ditemukan yang mengalami PJK yaitu berpendidikan SMP sebanyak (13 orang), dari segi pekerjaan ditemukan pada responden yang mengalami PJK yaitu sebagai pekerja wiraswasta sebanyak (11 orang).

\section{Kejadian Hipertensi}

Berdasarkan hasil peneltian didapatkan bahwa dari 45 responden 23 orang $(51,1 \%)$ mengalami hipertensi.

Hasil penelitian ini sejalan dengan penelitian sebelumnya yang dilakukan oleh Taufik dkk, 2016 mengenai "Analisa Faktor Resiko Penyakit Jantung Koroner Penderita Rawat Jalan Rumah Sakit Dokter Pringadi Medan" didapatkan kesimpulan 42,9\% responden mengalami hipertensi.

Tekanan darah yang tinggi
(hipertensi) dan menetap akan
menimbulkan trauma langsung terhadap dinding pembuluh darah arteri koronaria, sehingga memudahkan terjadinya arterosklerosis koroner. Hal ini menyebabkan angina pectoris, insufisiensi koroner dan miokard infark lebih sering didapatkan pada penderita hipertensi dibanding orang normal.

Tekanan darah sistolik diduga mempunyai pengaruh yang lebih besar. Kejadian penyakit jantung coroner pada hipertensi sering dan secara langsung berhubungan dengan tingginya tekanan darah sistolik. Penelitian Framingham selama 18 tahun terhadap penderita berusia 45-75 tahun mendapatkan hipertensi sistolik merupakan faktor pencetus terjadinya angina pectoris dan miokard infark.

Pemberian obat yang tepat pada hipertensi dapat mencegah terjadinya miokard infark dan kegagalan ventrikel kiri tetapi perlu juga diperhatikan efek samping dari obat-obatan dalam jangka panjang. Oleh sebab itu pencegahan terhadap hipertensi merupakan usaha yang jauh lebih baik untuk menurunkan resiko penyakit jantung koroner.

Menurut asumsi peneliti pada penelitian ini masih banyak ditemukan responden yang mengalami hipertensi, hal ini kemungkinan disebabkan karena sebagian besar tidak memiliki kesadaran untuk memeriksakan diri atau berobat kepelayanan kesehatan bahkan ada beberapa responden mengatakan tidak rutin minum obat dan berobat kepelayanan kesehatan sehingga tidak peduli dengan penyakit hipertensinya dan dianggap bahwa tekanan darah tinggi adalah hal biasa. Padahal bila tekanan darah tinggi tidak di manajemen dengan baik dapat menyebabkan berbagai komplikasi, tekanan darah tinggi dapat mempercepat denyut jantung. Nyeri dada, sesak napas, oleh karena itu dianjurkan pemberian obat hipertensi yang teratur. Pada penelitian ini yang mengalami hipertensi banyak ditemukan pada responden berumur $\geq 55$ tahun (14 orang), dan berpendidikan SMP (12 orang), dilihat dari perkerjaan wiraswasta (5 orang), ibu rumah tangga (5 orang), Petani (6 orang), dilihat dari jenis kelamin laki-laki (11 orang)

\section{Kebiasaan Merokok}

Berdasarkan hasil peneltian didapatkan dilihat bahwa dari 45 responden 26 orang $(57,8 \%)$ responden tidak perokok.

Hasil penelitian ini sejalan dengan penelitian sebelumnya yang dilakukan oleh Taufik dkk, 2016 mengenai "Analisa Faktor Resiko Penyakit Jantung Koroner Penderita Rawat Jalan Rumah Sakit Dokter Pringadi Medan" didapatkan kesimpulan $52,3 \%$ responden tidak merokok. 
Resiko terjadinya PJK akibat merokok turun menjadi 50\% setelah satu tahun berhenti merokok, dan menjadi normal setelah empat tahun berhenti merokok (Lecture Notes, 2012).

Berbagai hasil penelitian ilmiah telah membuktikan bahwa rokok merupakan salah satu faktor risiko utama dari penyakit jantung koroner. Menurut data WHO tahun 2008 Indonesia dinobatkan sebagai negara dengan konsumsi rokok terbesar nomor 3 setelah China dan India. Jumlah perokok Indonesia adalah 65 juta perokok atau $28 \%$ per penduduk, artinya dari setiap 4 orang penduduk Indonesia, terdapat seorang perokok (Cancer Helps. co.id, 2013). Begitu juga dengan temuan dari Global Adult Tobacco Survey (2011) menyatakan bahwa sebanyak 61,4 juta orang dewasa di Indonesia adalah perokok aktif.

Menurut asumsi peneliti pada penelian ini masih banyak ditemukan responden yang memiliki kebiasaan merokok, dan masih rendahnya keingan atau minat untuk berhenti merokok meskipun responden mengetahui akibat yang ditimbulkan oleh rokok beberapa reponden mengatakan sulit untuk berhenti akan kebiasaan merokok dan sudah pernah beberapa responden mencoba berhenti merokok dan beberapa minggu kemudian responden kembali untuk merokok kembali dari hasil penelitian yang telah dilakukan oleh peneliti didapatkan bahwa mayoritas usia mulai merokok responden pada penelitian ini adalah dari usia muda, dan hal tersebut berarti mayoritas merokok dan telah merokok lebih dari 4 tahun. Pada penelitian ini reponden yang memiliki kebiasaan merokok $\geq 4$ tahun banyak ditemukan pada responden berumur $\geq 55$ tahun (15 orang) yaitu ditemukan pada umumnya responden memulai merokok pada usia 17 tahun, berpendidikan SMP (11 orang), dan bekerja wiraswasta (12 orang), jenis kelamin laki-laki (19 orang).

\section{Riwayat Penyakit Jantung di Keluarga}

Berdasarkan hasil penetian didapatkan bahwa dari 45 responden 26 orang $(57,8 \%)$ tidak memiliki riwayat penyakit jantung di keluarga mengalami penyakit jantung koroner.
Penelitian sebelumnya menyatakan, riwayat penyakit jantung di keluarga PJK pada keluarga yang langsung berhubungan darah merupakan faktor risiko independen untuk terjadinya PJK, dengan rasio odd dua hingga empat kali lebih besar daripada populasi kontrol (Gray H. dkk 2005). Riwayat peyakit jantung di keluarga yang dimaksud dalam penelitian ini adalah riwayat keluarga premature $C A D$, bila terdapat riwayat PJK atau MI (Miokard Infark) pada ayah atau saudara laki-laki berusia 55 tahun ke bawah atau pada ibu atau saudara perempuan berusia 65 tahun ke bawah (O'Rourke R.A. dkk 2009).

Penelitian oleh Vaidya, Abhinav dkk (2013) juga menyatakan kemungkinan menderita PJK 5 kali lebih tinggi pada seseorang yang memiliki riwayat PJK prematur dibandingkan dengan yang tidak. Hasil penelitian ini didapatkan odds rasio yang lebih besar yaitu 9,4 kali lebih besar dibanding populasi kontrol. Dari 49 kasus, 14 orang menyatakan memiliki keluarga dekat dengan premature CAD dan dari 49 kontrol, 2 orang menyatakan memiliki keluarga dekat dengan premature CAD. Walaupun dalam mewawancarai responden telah dilakukan secara maksimal, peneliti menyadari keterbatasan dalam menggali riwayat premature CAD dalam keluarga disebabkan karena penilaian dilakukan secara subjektif dari responden.

Penyebab riwayat penyakit jantung di keluarga merupakan faktor risiko PJK antara lain karena riwayat keluarga yang positif dapat mempengaruhi usia onset PJK pada keluarga dekat (Gray H. dkk 2005). Dengan kata lain, perjalanan atherosklerosis pada keluarga dekatnya lebih cepat dibandingkan orang yang tidak memiliki riwayat keluarga dengan premature $\mathrm{CAD}$.

Penyebab lain adalah keturunan dari seorang penderita penyakit jantung koroner prematur diketahui menyebabkan perubahan dalam penanda aterosklerosis awal, misal reaktivitas arteria brakialis dan peningkatan tunika intima arteria karotis dan penebalan tunika media. Adanya hipertensi, seperti peningkatan hemosistein dan peningkatan lipid, ditemukan pada individu tersebut.Penelitian yang telah 
dilakukan mengesankan bahwa adanya riwayat dalam keluarga mencerminkan suatu predisposisi genetik terhadap disfungsi endotel dalam arteria koronaria (Brown C. T. 2006).

Menurut asumsi peneliti bahwa masih banyak responden yang memiliki riwayat penyakit jantung di keluarga yang mengalami penyakit jantung koroner, hal ini menunjukkan bahwa riwayat penyakit jantung dikeluarga terhadap kejadian penyakit jantung koroner dipengaruhi riwayat maternal yang berperan penting dalan peningkatan resiko penyakit jantung koroner.Beberapa mekanismenya disebabkan oleh efek hormonal pada metabolisme lipid, resistensi insulin, dan faktor trombogenesis.Pada penelitian ini responden yang memiliki riwayat penyakit jantung di keluarga banyak ditemukan pada responden berumur $\geq 55$ tahun (15 orang), berpendidikan SMP (13 orang) dan bekerja wiraswasta (11 orang), dan berjenis kelamin laki-laki (17 orang).

\section{B. Analisa Bivariat}

\section{Hubungan Hipertensi dengan Kejadian Penyakit Jantung Koroner}

Berdasarkan hasil peneltian didapatkan bahwa kejadian penyakit jantung koroner lebih tinggi pada responden yang mengalami hipertensi $(69,6 \%)$ dibandingkan responden yang tidak hipertensi $(31,8 \%)$. Sedangkan yang tidak mengalami penyakit jantung koroner lebih tinggi pada responden yang mengalami tekanan darah normal $(68,2 \%)$ dibandingkan dengan responden yang hipertensi $(30,4 \%)$. Hasil uji statistik ChiSquare didapatkan nilai $\mathrm{p}$ value 0,025 $(\mathrm{p}<0,05)$ artinya terdapat hubungan hipertensi dengan kejadian penyakit jantung koroner di Poliklinik Jantung RST Dr. Reksodiwiryo Padang tahun 2018.

Hasil penelitian ini sejalan dengan penelitian sebelumnya yang dilakukan oleh Taufik dkk, 2016 mengenai "Analisa Faktor Resiko Penyakit Jantung Koroner Penderita Rawat Jalan Rumah Sakit Dokter Pringadi Medan" didapatkan kesimpulan bahwa terdapat hubungan hipertensi dengan kejadian penyakit jantung koroner.

Penyakit Jantung koroner terjadi karena berbagai faktor, diantaranya adalah karena penyakit hipertensi atau tekanan darah tinggi.Hipertensi menyebabkan otot jantung bekerja sangat keras untuk memompa darah keseluruh tubuh, sehingga mengakibatkan jantung mengalami kecapekan atau istilahnya gangguan. Jika hal ini dibiarkan terus-menerus tanpa ada penanganan khusus maka otot-otot jantung akan rusak dan jantung tidak bisa berfungsi dengan baik, sehingga mengakibatkan penyakit jantung khusunya penyakit jantung koroner.

Menurut asumsi peneliti bahwa adanya hubungan hipertensi dengan kejadian penyakit jantung koroner, dapat terilihat dari kecendrungan responden yang mengalami penyakit jantung koroner pada responden yang mengalami hipertensi, hal ini memungkinkan disebabkan karena pemahaman tentang cara mengontrol penyakit hipertensi dalam hal ini memungkinkan disebabkan karena masih banyak responden yang berpendidikan rendah seperti SMP $(37,8 \%)$ dan SD $(11,1 \%)$. Dalam penelitian ini ditemukan 7 orang responden memiliki tekanan darah normal tapi masih mengalami penyakit jantung koroner, hal ini disebabkan karena faktor usia, riwayat penyakit jantung dikeluarga dan memiliki kebiasaan merokok dan dapat dibuktikan dari penelitian terlihat 7 orang responden yang mengalami penyakit jantung koroner tersebut mengalami 3 faktor tersebut.

2. Hubungan Kebiasaan Merokok dengan Kejadian Penyakit Jantung Koroner

Berdasarkan hasil peneltian didapatkan bahwa kejadian penyakit jantung koroner lebih tinggi pada responden yang perokok $(78,9 \%)$ dibandingkan yang tidak perokok $(30,8 \%)$. Sedangkan yang tidak mengalami penyakit jantung koroner lebih tinggi pada responden yang tidak perokok $(69,2 \%)$ dibandingkan dengan yang perokok $(21,1 \%)$. Hasil uji statistik Chi-Square didapatkan nilai $\mathrm{p}$ value $0,000 \quad(\mathrm{p}<0,05)$ artinya terdapat hubungan kebiasaan merokok dengan kejadian penyakit jantung koroner di Poliklinik Jantung RST. Dr. Reksodiwiryo Padang tahun 2018.

Hasil penelitian ini sejalan dengan penelitian yang dilakukan oleh Mamat 
(2010). Dengan adanya kebiasaan merokok mempunyai resiko 2,3 kali lebih besar untuk teerjadinya PJK dibandingkan dengan yang tidak kebiasaan merokok. Kebiasaan merokok mempunyai hubungan bermakna secara statistik untuk terjadinya PJK ( $\mathrm{p}=0,028)$.

Resiko terjadinya PJK akibat merokok turun menjadi $50 \%$ setelah satu tahun berhenti merokok, dan menjadi normal setelah empat tahun berhenti merokok (Lecture Notes, 2012). Teori yang dikemukakan oleh Fitriani Umar dkk, pada penelitian di Makassar tahun 2011, bahwa lama merokok > 10 tahun merupakan salah satu faktor risiko terjadinya PJK. Semakin lama seseorang merokok, semakin besar kemungkinan untuk menderita PJK dan semakin lama pula orang tersebut terpapar oleh asap rokok. Penelitian yang dilakukan oleh Rusni Mato dkk, di Makassar pada tahun 2013 sebelumnya dikemukakan bahwa risiko kematian akibat penyakit jantung koroner berkurang sebanyak 50\% pada tahun pertama sesudah rokok dihentikan dan kembali seperti tidak merokok setelah berhenti merokok 10 tahun. Menurut Bustan dikutip dari 10 lama seseorang merokok dapat di klasifikasikan menjadi kurang dari 10 tahun atau lebih dari 10 tahun.Semakin awal seseorang merokok, maka semakin sulit untuk berhenti merokok. Semakin muda usia orang merokok, akan semakin besar pengaruhnya.

Data yang diperoleh berdasarkan tipe perokok yang dinilai melalui banyak rokok yang dihisap, sampel dengan penyakit PJK sebagian besar menghisap rokok >6 batang/hari dengan kategori perokok.Teori Dr. Judith Mackay dan Dr. George A. Mensah mengatakan insidensi PJK dua kali lebih tinggi pada perokok dan empat kali lebih tinggi pada perokok berat dibandingkan dengan yang tidak merokok.

Data yang diperoleh berdasarkan jenis rokok yang dihisap, bahwa pasien dengan penyakit PJK sebagian besar menghisap jenis rokok kretek.Pada pasien yang non PJK sebagian besar menghisap jenis rokok putih dan yang menghisap jenis rokok kretek.Teori yang dikemukakan pada penelitian Fitriani Umar dkk,bahwa risiko
PJK secara signifikan 3 kali lebih besar pada orang yang merokok kretek. Sebagaimana diketahui bahwa rokok kretek memiliki kandungan nikotin dan tar yang cukup tinggi. Di Indonesia ada dua jenis produk rokok yang dikenal yaitu rokok putih dan rokok kretek.rokok kretek, yakni rokok yang memiliki ciri khas adanya campuran cengkeh pada tembakau. Sedangkan rokok putih, adalah rokok dengan atau tanpa filter dan cengkeh hanya menggunakan tembakau.

Menurut asumsi peneliti bahwa adanya hubungan kebiasaan merokok dengan kejadian penyakit jantung koroner, dapat dilihat dari kecendrungan responden yang mengalami penyakit jantung koroner pada responden yang merokok, hal ini kemungkinan disebabkan karena pada penelitian ini banyak responden berjenis kelamin laki-laki, dimana mayoritas kaum laki-laki memiliki kebiasaan merokok. Pada penelitian ini ditemukan 2 orang responden tidak merokok tapi masih mengalami penyakit jantung koroner, hal ini disebabkan karena faktor hipertensi dan adanya riwayat penyakit jantung di keluarga.

\section{Hubungan Riwayat Penyakit Jantung di Keluarga dengan Kejadian Penyakit Jantung Koroner \\ Berdasarkan hasil peneltian} didapatkan bahwa kejadian penyakit jantung koroner lebih tinggi pada responden yang memiliki riwayat keluarga $(73,7 \%)$ dibandingkan yang tidak memiliki riwayat keluarga $(34,6 \%)$. Sedangkan yang tidak mengalami penyakit jantung koroner lebih tinggi pada responden yang tidak memiliki riwayat keluarga $(65,4 \%)$ dibandingkan dengan yang memiliki riwayat keluarga (26,3\%). Hasil uji statistik Chi-Square didapatkan nilai $\mathrm{p}$ value 0,000 $(p<0,05)$ artinya terdapat hubungan riwayat keluarga dengan kejadian penyakit jantung koroner di Poliklinik Jantung RST. Dr. Reksodiwiryo Padang tahun 2018.

Hasil penelitian ini sejalan dengan penelitian sebelumnya yang dilakukan oleh Taufik dkk, 2016 mengenai "Analisa Faktor Resiko Penyakit Jantung Koroner Penderita Rawat Jalan Rumah Sakit Dokter 
Pringadi Medan" didapatkan kesimpulan bahwa terdapat hubungan riwayat keluarga dengan kejadian penyakit jantung koroner.

Riwayat keluarga PJK yang langsung berhubungan darah yang berusia kurang dari 70 th merupakan faktor resiko independen untuk terjadinya PJK, dengan rasio odd dua hingga empat kali lebih besar dari pada populasi control, agregasi PJK keluarga menandakan adanya predisposisi genetic pada keadaan ini. Terdapat beberapa bukti bahwa riwayat keluarga yang positif dapat mempengaruhi usia onset PJK pada keluarga dekat.

Menurut asumsi peneliti bahwa adanya hubungan riwayat penyakit jantung dikeluarga dengan kejadian penyakit jantung koroner pada responden yang memiliki riwayat penyakit jantung di keluarga, hal ini tidak dapat di pungkiri faktor keturunan memiliki peran terhadap kejadian penyakit jantung koroner.Pada penelitian ini ditemukan 2 orang responden tidak memiliki riwayat penyakit jantung dikeluarga tapi masih ditemmukan mengalami penyakit jantung koroner, hal ini disebabkan karena adanya faktor penyakit hipertensi dan kebiasaan merokok.

\section{KESIMPULAN}

Lebih dari separoh $(51,1 \%)$ responden mengalami kejadian penyakit jantung koroner di Poliklinik Jantung RST. Dr. Reksodiwiryo Padang tahun 2018. Lebih dari separoh $(51,1 \%)$ responden mengalami hipertensi di Poliklinik Jantung RST. Dr. Reksodiwiryo Padang tahun 2018. Lebih dari separoh $(57,8 \%)$ responden merokok di Poliklinik Jantung RST Dr. Reksodiwiryo Padang tahun 2018. Lebih dari separoh $(51,1 \%)$ responden memiliki riwayat penyakit jantung di keluarga mengalami penyakit jantung koroner di Poliklinik Jantung RST. Dr. Reksodiwityo Padang tahun 2018. Terdapat hubungan hipertensi dengan kejadian penyakit jantung koroner di Poliklinik Jantung RST. Dr. Reksodiwiryo Padang tahun 2018.. Terdapat hubungan resiko merokok dengan kejadian penyakit jantung koroner di Poliklinik Jantung RST. Dr. Reksodiwiryo Padang tahun 2018.. Terdapat hubungan riwayat penyakit jantung di keluarga dengan kejadian penyakit jantung koroner di Poliklinik Jantung RST Dr. Reksodiwiryo Padang tahun 2018.

\section{DAFTAR PUSTAKA}

AHA.2013.BAB II Tinjauan Pustaka. Universitas Sumatera Utara. http://repository.usu.ac.id/bitstream/123456 789/45519/4/Chapter\%2011.pdf. Diakses pada tanggal 10 Oktober 2017

Abdul Majid.2016.Asuhan Keperawatan pada Pasien dengan Gangguan Sistem Kardiovaskuler. Yokyakarta : Pustaka Baru Press

Brunnner \& suddarth handbooks (2010) Brown C. T. 2006. Penyakit Aterosklerotik Koroner, dalam Price, S.A. danWilson,L.M., Patofisiologi Konsepkonsep Proses Penyakit,diterjemahkan oleh Pendit, B.U., Hartanto, H., Wulansari, P., Susi, N. DanMahanani, D.A., Volume 2, Edisi 6, 579-585, Penerbit Buku KedokteranEGC, Jakarta

Clevo, Rendy, Margaret,2012.Keperawatan Medical Bedah Penyakit Dalam.Jogjakarta : Nuha Medika

Clara. Larasati. 2012. Faktor-faktor yang Berhubungan dengan Penyakit Jantung Koroner pada Pasien Rawat Inap di RS Khusus Jantung Sumatera Barat Skripsi.Padang : S1 Keperawatan Unand Padang

Corwin, 2001. Resiko PJK secara langsung berhubungan dengan tekanan darah. http://repository.usu.ac.id/bitstream/12345 6789/45519/4/Chapter\%2011.pdf. Diakses pada tanggal 10 Oktober 2017

Cancer Helps. co.id, 2013. Stop Kanker. Jakarta : Agro Media Pustaka

Depkes RI. 2006. Buku Saku Gaya Hidup Sehat.Jakarta : Depkes RI

Dinas Kesehatan Provinsi Sumatera Barat, 2016. Profil Kesehatan Propinsi Sumatera Barat. Padang.

Erasta, A.2012. Hubungan faktor resiko mayor penyakit jantung koroner dengan skor pembuluh darah koroner dari hasil angiografi koroner di RSUP Dr. Kariadi:Semarang.http://download.portalg aruda.org/article.php?article $=73706 \& v a l=$ 
4695. Diakses pada tanggal 01 Oktober 2017

Elizabeth J. Corwin,2001.Buku Saku Patofisiologi. Penerbit Buku Kedokteran:EGC

Fitriani Umar dkk,2011. Faktor risiko terjadinya PJKdi Makassar. Jurnal Penelitian. Jakarta : Universitas Indonesia

Gray H. dkk 2005. Lecture Notes : Kardiologi. (4th. ed). Jakarta: Erlangga

Huon, Keith, John,Iain, et, all.2012.Lecture Notes Kardiologi. Edisi Keempat.Jakarta : EMC

https://www.google.co.id/?gws_rd=cr,ssl\&ei=_5 oUWP_pKYnhvAS2q76gCQ\#q=angka+k ejadian+jantung+koroner+menurut+data+ kemenkes+ri+2016. Diakses pada tanggal 26 Oktobe 2018

http://www.depkes.go.id/article/view/201410080 002/lingkungan-sehat-jantung-sehat.html. Diakses pada tanggal 29 Oktober 2017

http://www.depkes.go.id/pdf.php?id=141127000 11. Diakses pada tanggal 29 Oktober 2017

http://www.ahlinyapenyakitjantung.web.id/angka -kematian-penyakit-jantung-di-indonesia/. Diakses pada tanggal 29 Oktober 2017

Indrawati, Lina.2012.Analisis faktor yang berhubungan dengan kemampuan pasien penyakit jantung koroner melakukan pencegahan sekunder faktor resiko di RSPAD Gatot Soebroto. Jakarta:Universitas Indonesia.

Judith Mackay dan George A (2014), Insiden Infark Miokard dan Kematian Akibat PJK.

Kabo, Prof. Dr. Peter.2014.Penyakit Jantung Koroner.Jakarta : FKUI.

Kemenkes RI, 2014. Profil Kesehatan Indonesia : Kejadian Penyakit Jantung Koroner. Jakarta.

Lecture Notes, 2012. Faktor-faktor yang berhubungan dengan penyakit jantung koroner. Jakarta.

Lily I. Rilantono.2012.Penyakit kardiovaskuler $(P K V)$. Fakultas Kedokteran Universitas Indonesia.

Lukito, 2015. Kejadian penyakit jantung koroner di Indonesia. Jakarta.

Mamat Supriyono, 2010. Faktor-faktor yang Berhubungan terhadap Kejadian Kejadian Penyakit Jantung Koroner pada Kelompok Usia $\leq 45$ Tahun. https://core.ac.uk/download/pdf/11717772. pdf
Muttaqin, Arif.2012. Pengantar Asuhan Keperawatan Klien dengan Gangguan Sistem Kardiovaskular. Jakartan: Salemba Medika.

Nasti, Pragustia.2014.Fakor-Faktor Yang Berhubungan dengan Serangan Jantung Berulang Pada Pasien Dengan Jantung Koroner di Bangsal Jantung RSUP. DR. M. Djamil .Skripsi.Padang : STIKes YPAK Padang.

Nanda Internasional.2015.. Buku Ajar Keperawatan Medical Bedah Jogjakarta : Perpustakaan Nasional

Notoatmodjo, Prof. Dr. Soekidjo.2012.Metodologi Penelitian Kesehatan. Jakarta : Rineka Cipta

Notoatmodjo, Prof. Dr. Soekidjo.2005.Metodologi Penelitian Kesehatan. Jakarta: Rineka Cip

Notoatmodjo, Prof. Dr. Soekidjo.2002Metodologi Penelitian Kesehatan. Jakarta: Rineka Cipta

Nursalam.2011.Konsep dan Penerapan Metodologi Penelitian Ilmu Keperawatan. Jakarta: Salemba Medika

O'Rourke R.A. dkk 2009. Valvular heart disease. Dalam; Libby P, Bonow RO, Mann DL, Zippes DP, ed. Braunwald's heart disease: a textbook of cardiovascular medicine. Edisi kedelapan. Philadelphia: Saunders Elsevier

Philip 1 dkk,2008. Survei epidemiologi Riwayat Penyakit Jantung. Jakarta.

Rahmatina, Herman, PhD, AIF,2010.Buku Ajar Fisiologi Jantung.Jakarta : EGC

Rendy dan Margareth, 2012. Faktor pencetus terjadinya Miokard Infark. Jakarta.

Rikesdas, 2013. Riset Kesehatan Dasar. Jakarta.

Rilantono, 2012. 5 Rahasia Penyakit Kardiovaskular (PKV). Jakarta: Badan. Penerbit Fakultas Kedokteran Universitas Indonesia

Smeltzer, Suzanne C dan Barre.2001.Buku Ajar Keperawatan Medikal Bedah Brunner dan Suddarth Edisi 8 Vol 1. Jakarta : EGC

Taufik dkk, 2016 mengenai "Analisa Faktor Resiko Penyakit Jantung Koroner Penderita Rawat Jalan Rumah Sakit Dokter Pringadi Medan. Jurnal Penelitian.

Vaidya, Abhinav dkk, 2013. Hubungan riwayat riwayat PJK prematur dengan kejadian PJK. Jurnal Penelitian. 
WHO.2014. Cardiovascular Disease Risk Factors. Pdf [cited 2015-1809].http://www.ahlinyapenyakitjantung.we b.id/angka-kematian-penyakit-jantung-diindonesia/.dpuf. Diakses pada tanggal 28 Oktober 2018

WHO.2010.Physical Activity: In Guide to Community Preventive Services .http://repository.usu.ac.id/bitstre am/123456789/27419/4/Chapter\%2011.pd f.2010. Diakses pada tanggal 28 September 2018 